\title{
Repellent Effects of Selected Organic Leaf Extracts of Tithonia diversifolia (Hemsl.) A. Gray and Vernonia lasiopus (O. Hoffman) against Sitophilus zeamais Motschulsky (Coleoptera: Curculionidae)
}

\author{
Stephen Maina Gitahi $\mathbb{D}^{1},{ }^{1}$ Mathew Ngugi Piero ${ }^{(D)},{ }^{1}$ David Nganga Mburu, \\ and Alex Kingori Machocho ${ }^{2}$ \\ ${ }^{1}$ Department of Biochemistry, Microbiology and Biotechnology, Kenyatta University, P.O. Box 4844-00100, Nairobi, Kenya \\ ${ }^{2}$ Department of Chemistry, Kenyatta University, P.O. Box 43844-00100, Nairobi, Kenya
}

Correspondence should be addressed to Stephen Maina Gitahi; gitahism@gmail.com

Received 14 August 2020; Revised 14 February 2021; Accepted 16 February 2021; Published 26 February 2021

Academic Editor: Isabel Del Hierro

Copyright (C) 2021 Stephen Maina Gitahi et al. This is an open access article distributed under the Creative Commons Attribution License, which permits unrestricted use, distribution, and reproduction in any medium, provided the original work is properly cited.

\begin{abstract}
Introduction. Sitophilus zeamais infestation is among the major setbacks to sustainable maize farming and availability. It causes an estimated annual loss of $5-10 \%$ and $20-30 \%$ of the total maize grains loss in the temperate and tropical zones, respectively. Although synthetic pesticides are quick and effective in managing crop pests, their overuse and misuse is discouraged due to their detrimental effects on human and environment. Natural pesticidal products that are extracted from plants are particularly gaining importance as an alternative to synthetic pesticides. They are available, easily biodegraded and have low toxicity to nontarget organisms. Most botanical pesticides act on insects by repelling them away from the crops in the field or in the stores. Therefore, this study aimed to determine repellency potential of organic leaf extracts of Tithonia diversifolia and Vernonia lasiopus on S. zeamais. Materials and methods. The phytochemical profile of T. diversifolia and V. lasiopus was determined using GC-MS. Laboratory-based experiments were carried out using area preference method to assess the efficacy of the extracts against weevils for a test period of $5 \mathrm{~h}$. Six groups of experiments were set up with ten S. zeamais in each test: positive control (Actellic), negative control (solvent only), and four different experimental extract concentrations (25, 50, 75, and 100\%). Results. The results indicated that $T$. diversifolia and $V$. lasiopus leaf extracts possess potent repellency effect on weevils. All the extracts simply discouraged S. zeamais from the treated areas recording significantly good levels of repellent activities between 26 and $96 \%$. Furthermore, the GC-MS analysis manifested the presence of bioactive compound in the extracts which are associated with the repellency effects. Conclusion. The study scientifically confirms the traditional use of the T. diversifolia and V. lasiopus and provides important platform for further study on the extracts as bioresource of botanical repellent.
\end{abstract}

\section{Introduction}

Maize (Zea mays) is considered as the queen of cereals in sub-Saharan Africa (SSA). It is one of the most important crops in the world with highest production and productivity under both irrigated and rain-fed agricultural systems in the semiarid and arid tropics, especially in SSA [1]. In view of its great importance, betterment in agronomical aspects of maize should receive equally big attention globally, a lot need to be done to increase maize production and more importantly reduce loss of maize produced for food security to be realized [2]. However, there are many constraints affecting maize production.

Among the many challenges of maize production, maize is exposed to insect pest attack prior to harvest and in storage, but the storage pests form a major cause of grain loss [3]. These pests include S. zeamais, S. oryzae, T. castaneum, and E. cautella. The most common pests of stored grain are 
the larger grain borer and maize weevils [4]. However, S. zeamais is the most predominant and destructive of all these pests that need to be managed under all cost [5].

Repellents can be an effective method for control measure of weevils on stored grains. The most conventionally effective control measure of weevils is by use of synthetic repellent pesticides [6]. However, these chemicals generally tend to be expensive, with short-lived effectiveness and risky on human health among other adverse effects [7]. This critical flaws leads to ongoing research for new and effective repellents, which provide longer protection against weevils, while remaining safe, eco-friendly, and reasonably priced [8].

Medicinal plants also form an integral intervention in the management of $S$. zeamais. This is because they are generally regarded to be safe on human health and environment $[7,9]$. The use of plants as storage pest repellents is very old. Some of these plants that are currently used in the management of weevils include A. heterophyllus, A. sativum and $O$. basilicum, and Pterocarpus santalinoides among others [10-12]. Other than their famous importance in gardens as animal feed, $T$. diversifolia and $V$. lasiopus are some of the most important plants of the Asteraceae family with numerous medicinal values. Tithonia diversifolia is used in the treatment of fungal infections, inflammation, pain, malaria, and diabetes among other diseases $[13,14]$. Tithonia diversifolia is also used to control fleas, jigger, and C. maculatus [15-17] while V. lasiopus is used in management of malaria, fungal infections, worms, and ticks [18-21].

People in Embu County use these plants traditionally in the management of S. zeamais in stored grains. However, no scientific research on the described pesticidal activity of $T$. diversifolia and $V$. lasiopus against weevils has been published, and experimental data about their repellent properties are scanty. It is against this background that this study was conceived and designed to explore the antipyretic potential of the selected organic leaf extract of $T$. diversifolia and $V$. lasiopus against weevils.

\section{Materials and Methods}

2.1. Plant Sample Collection. The plants used in this study, $T$. diversifolia and V. lasiopus, were collected from their natural habitat in Makunguru Village, Nthawa Location, Siakago Division, Mbeere North Subcounty, Embu County, Kenya. The GPS location for T. diversifolia and $V$. lasiopus specimens was $0^{\circ} 35^{\prime} 39^{\prime \prime} \mathrm{S}, 37^{\circ} 38^{\prime} 10^{\prime \prime} \mathrm{E}$ and $0^{\circ} 35^{\prime} 39.51^{\prime \prime} \mathrm{S}$, $37^{\circ} 38^{\prime} 23.62^{\prime \prime} \mathrm{E}$, respectively. The fresh leaves were identified and collected from mature plants with the help of local herbalists. The folklore information obtained included the local name of the plants, part of plant harvested, season of harvesting, method of preparation, and other medicinal importance of the plants. Samples were properly sorted out, cleaned, and transported in bags to Kenyatta University, in the Biochemistry, Microbiology, and Biotechnology departmental laboratories. The plant samples were provided to an acknowledged taxonomist for botanical authentication and voucher specimens deposited at the Kenyatta University Pharmacy and Complementary/Alternative Medicine research herbaria for future reference. The specimens were assigned voucher numbers as SMG-V1/17 and SMG-V2/17 for $T$. diversifolia and $V$. lasiopus, respectively.

2.2. Sample Preparation and Extraction. The leaves of $T$. diversifolia and $V$. lasiopus were air dried separately under shade and room temperature for a period of two weeks. The leaves were separately ground into fine powder using a grinding electric mill and sieved using a $300 \mu \mathrm{m}$ mesh. The powder was used for organic solvent extraction following the guideline used by [22], as well as [23].

Extraction was separately done with dichloromethane and ethyl acetate $200 \mathrm{~g}$ of each plant leaf powders were separately soaked in $200 \mathrm{ml}$ of the respective solvents for 12 hours. The extracts were decanted, and $200 \mathrm{ml}$ of solvent was added and set for 24 hours. After 24 hours, filtration was done again and $200 \mathrm{ml}$ of the respective solvent was added for the final extraction until 48 hours when the last filtrate was obtained. Occasional swirling was done to ensure thorough extraction. Aluminum foil and cotton wool were always used to cover the flasks to prevent escape of solvent. Muslin cloth and Whatman No. 1 papers were used for the filtrations of the extracts. The extract filtrates were then concentrated in vacuum using a Heidolph rotary evaporator, and the solvent was recovered. The concentrates were further allowed to dry to remove traces of the solvents and yield dry extracts. All the extracts were later kept in sample bottles and refrigerated at $4^{\circ} \mathrm{C}$.

\subsection{Preparation of Extract Concentrations. The plant extract} concentrates were diluted with respective solvents at a concentration of $1 \mathrm{gml}^{-1}$, and this was termed as stock solution $(100 \% \mathrm{w} / \mathrm{v}$ concentration) as described by Deshmukh and Borle [24] with limited modifications. The concentrations used were as follows: $25 \%(\mathrm{w} / \mathrm{v}), 50 \%(\mathrm{w} / \mathrm{v}), 75 \%$ $(\mathrm{w} / \mathrm{v})$, and $100 \%(\mathrm{w} / \mathrm{v})$. These extract concentrations were prepared as follows: the $25 \%(\mathrm{w} / \mathrm{v})$ concentration was prepared by diluting $1 \mathrm{ml}$ of the stock solution with $3 \mathrm{ml}$ of solvent to make up $4 \mathrm{ml}$. The $50 \%(\mathrm{w} / \mathrm{v})$ concentration was prepared by diluting $2 \mathrm{ml}$ of stock solution with $2 \mathrm{ml}$ of the solvent to make up $4 \mathrm{ml}$ while for the $75 \%(\mathrm{w} / \mathrm{v})$ concentration, and $1 \mathrm{ml}$ of the solvent was added to $3 \mathrm{ml}$ of stock solution to make up $4 \mathrm{ml}$.

2.4. Preparation of Maize Weevil (Sitophilus zeamais). A stock culture of the maize weevil, S. zeamais, was initiated by collecting adult weevils from the infested maize grains and cultured in their food media (susceptible whole maize grains) under fluctuating ambient temperature and relative humidity. Two hundred unsexed adult weevils were introduced into five two-litre glass bottles with $500 \mathrm{~g}$ of maize. The insects were allowed to oviposit for seven days after which they were sieved out and subsequently used for the bioassay experiments. The insect stock culture was further maintained in glass bottles of two-litre capacity containing the maize grains. The weevils were reared subsequently by replacing devoured and infested grains with fresh, clean, 
uninfected grains in containers covered with muslin cloth to allow for air circulation and prevent escape of insects. The muslin cloths covering the containers were held in place with rubber bands. The maize dust was periodically sieved in order to prevent the growth of mould, which may lead to the caking of grains and ultimate death of the insects. Sitophilus zeamais breeding and the experiments were conducted at an ambient temperature of $27 \pm 2^{\circ} \mathrm{C}$, relative humidity of $75 \pm 5.5 \%$, and suitable photoperiod (LD 12:12).

2.5. Gas Chromatography-Mass Spectrometry (GC-MS) Analysis. Analysis of the sample was carried out using GCMS (7890/5975 Agilent Technologies, Inc., Beijing, China) consisting of a gas chromatograph interfaced to a mass spectrometer. The GC-MS was equipped with an HP-5 MS (5\% phenyl methyl siloxane) low-bleed capillary column of $30 \mathrm{~m}$ length, $0.25 \mathrm{~mm}$ diameter, and $0.25 \mu \mathrm{m}$ film thickness. For GC-MS detection, an electron ionization system with an ionization energy of $70 \mathrm{Ev}$ was used. The carrier gas used was helium $(99.99 \%)$ at a constant flow rate of $1.25 \mathrm{ml} / \mathrm{min}$ in split mode. The injector and mass transfer line temperature were set at $250^{\circ} \mathrm{C}$ and $200^{\circ} \mathrm{C}$, respectively, and an injection volume of $1 \mu \mathrm{l}$ was employed. The oven temperature was programmed from $35^{\circ} \mathrm{C}$ for $5 \mathrm{~min}$, with an increase of $10^{\circ} \mathrm{C} /$ min to $280^{\circ} \mathrm{C}$ for $10.5 \mathrm{~min}$, then $50^{\circ} \mathrm{C} / \mathrm{min}$ to $285^{\circ} \mathrm{C}$ for 29.9 min with a run time of $70 \mathrm{~min}$. The MS operating parameters were as follows: ionization energy, $70 \mathrm{eV}$; ion source temperature, $230^{\circ} \mathrm{C}$; solvent cut time, $3.3 \mathrm{~min}$; scan speed, $1666 \mu / \mathrm{sec}$; scan range, $40-550 \mathrm{~m} / z$; and the interface temperature, $250^{\circ} \mathrm{C}$. Interpretation of mass-spectrum from GC-MS analysis was performed using the central database of the National Institute Standard and Technology (NIST) which contains more than 62,000 patterns. As for the unknown components, their spectrum was compared with those which are known from the NIST library.

2.6. Research Design. The repellent assessment adopted a randomized controlled study design (RCD). The study used the area preference method [25]. To create the two experimental areas, Whatman No. 1 filter paper circles of $10 \mathrm{~cm}$ in diameter were cut into two halves. One milliliter of each extract treatment at predetermined concentrations of 25, 50, 75 , and $100 \%$ was uniformly applied with a pipette to a half filter paper disc as uniformly as possible. This half filter paper circle formed the treated test area of the experiments. The other half circle was treated with solvent only to serve as negative control area. All the discs were then air dried to evaporate solvents completely. For positive control, a conventional pesticide Actellic was applied on the treated area at the recommended rate of $2 \mu \mathrm{g} / \mathrm{ml}$.

A full filter paper was then remade by attaching the treated halves with the untreated halves with cellotape. The treated and the untreated half-circles were hence placed contiguously on the Petri dishes, and ten weevils were carefully introduced at the center of each filter paper disc in the Petri dish and covered well. Each treatment was replicated four times. The treatments were set up into six independent treatment groups as shown in Table 1. Each of all the six experiments including the control treatments were set out with four replications.

The number of weevils in the treated $\left(N_{t}\right)$ and control $\left(N_{c}\right)$ areas of preference was counted and recorded after every one hour for five hours. These numbers were then used to calculate percent repellency (PR) of each extract by using the formula described by [26]:

$$
\operatorname{PR}(\text { percentage of repellency })=\frac{\left(N_{c}-N_{t}\right)}{\left(N_{c}+N_{t}\right)} \times \frac{100}{1},
$$

where $N_{c}=$ the number of insects recorded in the control half and $N_{t}=$ the number of insects recorded in the treated half.

The index of repellency (IR) was then calculated using the formula described by [27]:

$$
\operatorname{IR}\left(\text { index of repellency) }=\frac{2 T}{T+C},\right.
$$

where $C$ and $T$ represent the number of insects on the untreated and treated areas of preference, respectively. The repellency index values were classified as repellency (values $<1$ ), neutral (values $=1$ ), and attractant (values $>1$ ) [27].

2.7. Data Management and Statistical Analysis. The number of weevils on both experimental areas $\left(N_{c}\right.$ and $\left.N_{t}\right)$ was obtained from all the different groups for each of the extracts of the two plants. The data obtained were recorded and tabulated on a broad spread sheet. Percent repellency (PR) and index of repellency (IR) were calculated using MS Excel program. The results of IR and PR were analyzed through descriptive statistics and presented as mean \pm SEM. These data were subjected to inferential statistics using one-way ANOVA followed by Tukey's post hoc test for separation and pairwise comparisons of means. Unpaired Student's $t$ test was used for pairwise separation and comparison of means between different treatment groups for the two plants. The significant difference between the treatments groups were reported at $p \leq 0.005$. All these statistical analyses were performed using Minitab version ${ }^{17}$ software as the statistical software. The resulting data of this study were presented in form of tables and bar graphs.

\section{Results}

3.1. Quantitative Phytochemical Analysis of the Selected Organic Leaf Extract of T. diversifolia and V. lasiopus. The GCMS results of the present study showed the presence of active insect repellent compounds in T. diversifolia and V. lasiopus as indicated in Tables 2 and 3 .

3.2. Repellent Activity of DCM Leaf Extracts of T. diversifolia and V. lasiopus against S. zeamais. Generally, the DCM leaf extracts of T. diversifolia and $V$. lasiopus repelled S. zeamais with repellency index (IP) values of less than one (Tables 4 and 5 ). Overall, the average repellency activities of the $T$. diversifolia and $V$. lasiopus extracts were largely dose dependent, as they resulted in a regular pattern of repellency, from the lowest to the highest dosages. In the first hour of the 
TABle 1: Treatment protocol for determination of repellency activities of T. diversifolia and V. lasiopus on S. zeamais.

\begin{tabular}{lcc}
\hline Group & Treated area & Control area \\
\hline I experimental group A & $25 \%$ plant extract (w/v) & Solvent only \\
II experimental group B & $50 \%$ plant extract (w/v) & Solvent only \\
III experimental group C & $75 \%$ plant extract (w/v) & Solvent only \\
IV experimental group D & $100 \%$ plant extract (w/v) & Solvent only \\
V positive control & Actellic & Solvent only \\
\hline
\end{tabular}

TABLE 2: Phytochemical analysis of insecticidal compounds in the DCM leaf extract of T. diversifolia and V. lasiopus.

\begin{tabular}{|c|c|c|c|c|}
\hline \multirow{2}{*}{ Compound name } & \multirow{2}{*}{ Chemical class } & \multirow{2}{*}{ Molecular formula } & \multicolumn{2}{|c|}{ Compound concentration (ng/g) } \\
\hline & & & T. diversifolia & V. lasiopus \\
\hline Squalene & TD & $\mathrm{C}_{30} \mathrm{H}_{50}$ & 392.50 & 149.90 \\
\hline$\beta$-Amyrin & TT & $\mathrm{C}_{30} \mathrm{H}_{50} \mathrm{O}$ & 522.35 & 183.79 \\
\hline$\alpha$-Copaene & ST & $\mathrm{C}_{15} \mathrm{H}_{24}$ & 4.32 & - \\
\hline Dodecanoic acid & FAD & $\mathrm{Cl}_{2} \mathrm{H}_{24} \mathrm{O}_{2}$ & 7.15 & - \\
\hline$\alpha$-Amyrin & TT & $\mathrm{C}_{30} \mathrm{H}_{50} \mathrm{O}$ & 177.89 & 48.08 \\
\hline Hexadecanoic acid & FAD & $\mathrm{C}_{16} \mathrm{H}_{31} \mathrm{O}_{2}$ & 402.48 & 65.37 \\
\hline Stigmasterol & ST & $\mathrm{C}_{29} \mathrm{H}_{48} \mathrm{O}$ & - & 13.74 \\
\hline Octadecanoic acid & FAD & $\mathrm{C}_{18} \mathrm{H}_{30} \mathrm{O}_{2}$ & 139.90 & 19.16 \\
\hline Indanol & $\mathrm{P}$ & $\mathrm{C}_{9} \mathrm{H}_{10} \mathrm{O}$ & & 5.21 \\
\hline Pentadecanone & FAD & $\mathrm{C}_{18} \mathrm{H}_{36} \mathrm{O}$ & 31.94 & - \\
\hline Docosanoic acid & FAD & $\mathrm{C}_{22} \mathrm{H}_{44} \mathrm{O}_{2}$ & 37.88 & - \\
\hline p-Xylene & $\mathrm{P}$ & $\mathrm{C}_{6} \mathrm{H}_{4}\left(\mathrm{CH}_{3}\right)_{2}$ & 4.69 & - \\
\hline Benzaldehyde & $\mathrm{BD}$ & $\mathrm{C}_{7} \mathrm{H}_{8} \mathrm{O}$ & 8.49 & - \\
\hline Tetradecanal & FAD & $\mathrm{C}_{14} \mathrm{H}_{28} \mathrm{O}$ & 9.75 & 5.53 \\
\hline Phytol, acetate & DT & $\mathrm{C}_{22} \mathrm{H}_{42} \mathrm{O}_{2}$ & 254.59 & 170.93 \\
\hline Methyl linoleate & DT & $\mathrm{C}_{19}{ }_{19} \mathrm{H}_{34} \mathrm{O}_{2}$ & 164.40 & 164.40 \\
\hline Phytol & DT & $\mathrm{C}_{20} \mathrm{H}_{40} \mathrm{O}$ & 159.82 & 051.17 \\
\hline Isophytol & DT & $\mathrm{C}_{20} \mathrm{H}_{40} \mathrm{O}$ & 007.05 & - \\
\hline Eugenol & $\mathrm{P}$ & $\mathrm{C}_{10} \mathrm{H}_{12} \mathrm{O}_{2}$ & 009.53 & 005.30 \\
\hline Linalool & MT & $\mathrm{C}_{10} \mathrm{H}_{18} \mathrm{O}$ & 007.34 & - \\
\hline Chondrillasterol & ST & $\mathrm{C}_{29} \mathrm{H}_{48} \mathrm{O}$ & - & 067.52 \\
\hline Methyl linoleate & FAD & $\mathrm{C}_{19} \mathrm{H}_{34} \mathrm{O}_{2}$ & 164.40 & 043.03 \\
\hline Nonadecene & FAD & $\mathrm{C}_{19} \mathrm{H}_{38}$ & - & 003.18 \\
\hline
\end{tabular}

P, phenolic; ST, sesquiterpenoid; TT, triterpenoid; DT, diterpenoid; MT, monoterpenoid; S, phytosterol, AD, aldehyde; $\mathrm{BD}$, benzyl derivatives; FAD, fatty acid derivatives.

experimental period, repellent activities of the T. diversifolia extracts were dose independent. The $T$. diversifolia extract dose of $75 \%$ evoked a greater repellency $(100 \%)$ as compared to that of $100 \%$ extract concentration (95\%) (Table 4 ).

After two hours of exposure to weevils, the T. diversifolia extract doses of 25 and $50 \%$ remained comparable to each other $(p>0.005$; Table 4$)$ but significantly different from the rest of treatment samples $(p<0.005$; Table 4$)$. The $T$. diversifolia extract dose of $100 \%$ caused a $100 \%$ repellent effect after the second and third hours of exposure to weevils. It was noted that these effects were not significantly different from that caused by the standard pesticide, Actellic ( $p>0.005$; Table 4$)$. The $T$. diversifolia extract dose of $25 \%$ caused the least repellent effects on weevils at the fourth hour of the experimental period (Table 4). It was observed that the mean percentage repellent effects of the $T$. diversifolia extracts after the 5 hours experimental period ranged between 33 and $96 \%$ (Table 4). Only the T. diversifolia extract doses of $75 \%$ and $100 \%$ manifested repellency activities that were not significantly different from the effects caused by Actellic ( $p>0.005$; Table 4$)$.
On the other hand, the DCM leaf extract of $V$. lasiopus remarkably repelled $S$. zeamais by an average of between 51 and $91 \%$ (Table 5) after the 5-hour duration of the experiment. The $V$. lasiopus extract concentration of $100 \%$ achieved the highest weevil repelling activity of $80 \%$ after one hour of exposure, which later decreased to $85 \%$ by the end of fifth hour of exposure to weevils (Table 5).

The least repellency activity was manifested by the $V$. lasiopus extract concentration of $50 \%$ at the fourth hour of exposure to weevils. Similar to the lower doses of the $V$. lasiopus extract (25 and 50\%), the higher doses of $75 \%$ and $100 \%$ also exhibited comparable weevil repellent effects throughout the experimental period ( $p>0.005$; Table 5 ).

It was also observed that the $V$. lasiopus extract dose of $25 \%$ produced high repellent effects of $70 \%$ and $65 \%$ after the second and fifth hours of exposure, respectively. This effectiveness was not significantly different from the effects caused by high extract doses (75 and 100\%) as well as the positive control $(p>0.005$; Table 5$)$.

On average, after the five hours of this experiment, it was observed that only the $V$. lasiopus extract concentration of $100 \%$ manifested repellency effects (0.09), which was not 
TAвLE 3: Phytochemical analysis of insecticidal compounds in the ethyl acetate leaf extract of T. diversifolia and V. lasiopus.

\begin{tabular}{|c|c|c|c|c|}
\hline \multirow{2}{*}{ Compound name } & \multirow{2}{*}{ Chemical class } & \multirow{2}{*}{ Molecular formula } & \multicolumn{2}{|c|}{ Compound concentration (ng/g) } \\
\hline & & & T. diversifolia & V. lasiopus \\
\hline Nonanoic acid & FAD & $\mathrm{C}_{9} \mathrm{H}_{18} \mathrm{O}_{2}$ & 008.05 & - \\
\hline Squalene & TT & $\mathrm{C}_{30} \mathrm{H}_{50}$ & 448.08 & 122.41 \\
\hline$\alpha$-Copaene & ST & $\mathrm{C}_{15} \mathrm{H}_{24}$ & 21.54 & 14.93 \\
\hline Limonene & MT & $\mathrm{C}_{10} \mathrm{H}_{16}$ & - & 005.06 \\
\hline Hexadecanoic acid & FAD & $\mathrm{C}_{16} \mathrm{H}_{32} \mathrm{O}_{2}$ & 789.58 & 321.66 \\
\hline Tetradecanal & FAD & $\mathrm{C}_{14} \mathrm{H}_{28} \mathrm{O}$ & 15.46 & - \\
\hline Tetradecanoic acid & FAD & $\mathrm{C}_{14} \mathrm{H}_{28} \mathrm{O}_{2}$ & 45.02 & 13.41 \\
\hline$\beta$-Amyrin & TT & $\mathrm{C}_{30} \mathrm{H}_{50} \mathrm{O}$ & 297.63 & 39.98 \\
\hline$\alpha$-Amyrin & TT & $\mathrm{C}_{30} \mathrm{H}_{50} \mathrm{O}$ & 20.78 & - \\
\hline Olean-12-ene acid & $\mathrm{TT}$ & $\mathrm{C}_{30} \mathrm{H}_{50}$ & 80.86 & - \\
\hline$\alpha$-Pinene & MT & $\mathrm{C}_{10} \mathrm{H}_{16}$ & - & 004.53 \\
\hline Widdrol & ST & $\mathrm{C}_{15} \mathrm{H}_{26} \mathrm{O}$ & 110.29 & \\
\hline Nerolidol & ST & $\mathrm{C}_{15} \mathrm{H}_{26} \mathrm{O}$ & 86.54 & 56.13 \\
\hline Caryophyllene oxide & ST & $\mathrm{C}_{15} \mathrm{H}_{24} \mathrm{O}$ & 19.33 & 11.87 \\
\hline$\alpha$-Bulnesene & ST & $\mathrm{C}_{15} \mathrm{H}_{24}$ & 4.57 & - \\
\hline Indole & $\mathrm{A}$ & $\mathrm{C}_{8} \mathrm{H}_{7} \mathrm{~N}$ & 11.33 & - \\
\hline Indanol & $\mathrm{P}$ & $\mathrm{C}_{9} \mathrm{H}_{10} \mathrm{O}$ & 16.03 & - \\
\hline Benzaldehyde & $\mathrm{BD}$ & $\mathrm{C} 7 \mathrm{H} 6 \mathrm{O}$ & 5.56 & 8.01 \\
\hline Vanillin & $\mathrm{P}$ & $\mathrm{C}_{8} \mathrm{H}_{8} \mathrm{O}_{3}$ & 4.69 & - \\
\hline Naphthalene & $\mathrm{P}$ & $\mathrm{C}_{12} \mathrm{H}_{12}$ & 6.48 & - \\
\hline Methyl linoleate & FAD & $\mathrm{C}_{19} \mathrm{H}_{34} \mathrm{O}_{2}$ & 370.28 & 121.30 \\
\hline Phytol & DT & $\mathrm{C}_{20} \mathrm{H}_{40} \mathrm{O}$ & 321.37 & 060.40 \\
\hline p-Xylene & $\mathrm{TT}$ & $\mathrm{C}_{6} \mathrm{H}_{4}\left(\mathrm{CH}_{3}\right)_{2}$ & - & 7.42 \\
\hline Phytol acetate & DT & $\mathrm{C}_{22} \mathrm{H}_{42} \mathrm{O}_{2}$ & 087.95 & 233.70 \\
\hline Sabinene & MT & $\mathrm{C}_{10} \mathrm{H}_{18} \mathrm{O}$ & - & 004.57 \\
\hline Eugenol & $\mathrm{P}$ & $\mathrm{C}_{10} \mathrm{H}_{12} \mathrm{O}_{2}$ & 016.89 & - \\
\hline Caryophyllene & $\mathrm{ST}$ & $\mathrm{C}_{15} \mathrm{H}_{24} \mathrm{O}$ & 019.33 & 011.87 \\
\hline Linalool & MT & $\mathrm{C}_{10} \mathrm{H}_{18} \mathrm{O}$ & - & 007.58 \\
\hline Citronellel & FAD & $\mathrm{C}_{14} \mathrm{H}_{26} \mathrm{O}_{2}$ & 116.29 & - \\
\hline Terpinen-4-ol & $\mathrm{MT}$ & $\mathrm{C}_{10} \mathrm{H}_{18} \mathrm{O}_{0}$ & 006.58 & 005.84 \\
\hline L- $\alpha$-terpineol & MT & $\mathrm{C}_{14} \mathrm{H}_{22}$ & 003.47 & - \\
\hline
\end{tabular}

P, phenolic; ST, sesquiterpenoid; A, alkaloids; TT, triterpenoid; DT, diterpenoid; MT, monoterpenoid; S, phytosterol; AD, aldehyde; BD, benzyl derivatives; FAD, fatty acid derivatives.

TABLE 4: Repellency activity of the DCM leaf extracts of T. diversifolia against S. zeamais.

\begin{tabular}{|c|c|c|c|c|c|c|c|}
\hline \multirow{2}{*}{$\begin{array}{l}\text { Concentration } \\
\text { (\% extract) }\end{array}$} & \multicolumn{5}{|c|}{ PR (mean $\% \pm$ S.E.M) ${ }^{\mathrm{m}}$ with exposure time (hr.) } & \multirow{2}{*}{$\begin{array}{c}\text { PR } \\
(\text { mean } \pm \text { S.E.M })^{\mathrm{n}}\end{array}$} & \multirow{2}{*}{$\begin{array}{c}\text { IP } \\
(\text { mean } \pm \text { S.E.M })^{\mathrm{n}}\end{array}$} \\
\hline & $1 \mathrm{hr}$ & $2 \mathrm{hr}$ & $3 \mathrm{hr}$ & $4 \mathrm{hr}$ & $5 \mathrm{hr}$ & & \\
\hline 25 & $\begin{array}{c}35.00 \pm 5.00^{c} \\
(0.65)\end{array}$ & $\begin{array}{c}45.00 \pm 5.00^{b} \\
(0.55)\end{array}$ & $\begin{array}{l}45.00 \pm 5.00^{\mathrm{b}} \\
(0.55)\end{array}$ & $\begin{array}{c}15.00 \pm 9.57^{\mathrm{b}} \\
(0.85)\end{array}$ & $\begin{array}{c}25.00 \pm 5.00^{b} \\
(0.75)\end{array}$ & $33.00 \pm 5.83^{\mathrm{b}}$ & $0.67 \pm 0.0583^{\mathrm{a}}$ \\
\hline 50 & $\begin{array}{r}65.00 \pm 5 \\
(0.35\end{array}$ & $\begin{array}{c}55.00 \pm 5.00^{\mathrm{b}} \\
(0.45)\end{array}$ & $\begin{array}{c}50.00 \pm 5.77^{\mathrm{b}} \\
(0.50)\end{array}$ & $\begin{array}{c}50.00 \pm 5.77^{\mathrm{b}} \\
(0.50)\end{array}$ & $\begin{array}{c}35.00 \pm 5.00^{\mathrm{b}} \\
(0.65)\end{array}$ & $51.00 \pm 4.84^{\mathrm{b}}$ & $0.49 \pm 0.0485^{\mathrm{a}}$ \\
\hline 75 & $\begin{array}{c}100.00 \pm 0.00^{\mathrm{a}} \\
(0.00)\end{array}$ & $\begin{array}{c}95.00 \pm 5.00^{\mathrm{a}} \\
(0.05)\end{array}$ & $\begin{array}{c}95.00 \pm 5.00^{\mathrm{a}} \\
(0.05)\end{array}$ & $\begin{array}{c}90.00 \pm 5.77^{\mathrm{a}} \\
(0.10)\end{array}$ & $\begin{array}{c}95.00 \pm 5.00^{\mathrm{a}} \\
(0.05)\end{array}$ & $95.00 \pm 1.56^{\mathrm{a}}$ & $0.05 \pm 0.0158^{b}$ \\
\hline 100 & $\begin{array}{c}95.00 \pm 5.00^{\mathrm{a}} \\
(0.05)\end{array}$ & $\begin{array}{c}100.00 \pm 0.0^{\mathrm{a}} \\
(0.00)\end{array}$ & $\begin{array}{c}100.00 \pm 0.00^{\mathrm{a}} \\
(0.00)\end{array}$ & $\begin{array}{c}90.00 \pm 5.77^{\mathrm{a}} \\
(0.10)\end{array}$ & $\begin{array}{c}95.00 \pm 5.00^{\mathrm{a}} \\
(0.05)\end{array}$ & $96.00 \pm 1.87^{\mathrm{a}}$ & $0.04 \pm 0.0187^{\mathrm{b}}$ \\
\hline Actellic & $\begin{array}{c}100.00 \pm 0.00^{\mathrm{a}} \\
(0.00)\end{array}$ & $\begin{array}{c}95.00 \pm 5.00^{\mathrm{a}} \\
(0.05)\end{array}$ & $\begin{array}{c}100.00 \pm 0.00^{\mathrm{a}} \\
(0.00)\end{array}$ & $\begin{array}{c}100.00 \pm 0.00^{\mathrm{a}} \\
(0.00)\end{array}$ & $\begin{array}{c}95.00 \pm 5.00^{\mathrm{a}} \\
(0.05)\end{array}$ & $98.00 \pm 1.22^{\mathrm{a}}$ & $0.02 \pm 0.0122^{b}$ \\
\hline
\end{tabular}

Values followed by the same superscript within the same column are not significantly different $(p>0.005)$ determined by one-way ANOVA followed by Turkey's test. ${ }^{\mathrm{m}}$ Values were means based on four extract concentrations, four replicates $(n=4)$. ${ }^{\mathrm{n}}$ Values were means obtained over the 5-hour test duration $(n=5)$. Figures in parenthesis indicate the repellency index (IP $<1$ for repellency, IP $=1$ for neutral, and IP $>1$ for attractant).

significantly different from that portrayed by synthetic pesticide, Actellic (0.02) ( $p>0.005$; Table 5).

The comparison of the repellent effects of DCM leaf extracts of T. diversifolia and V. lasiopus indicated that the $V$. lasiopus extract was significantly more effective than the
T. diversifolia extract at the extract dose of $25 \%(p<0.005$; Figure 1). However, the T. diversifolia extract dose of $75 \%$ manifested a significantly higher effectiveness than the $V$. lasiopus extract at similar concentration $(p<0.005$; Figure 1). It was also evident that there was no significant 
TABLE 5: Repellent activity of DCM leaf extracts of $V$. lasiopus against S. zeamais.

\begin{tabular}{|c|c|c|c|c|c|c|c|}
\hline \multirow{2}{*}{$\begin{array}{l}\text { Concentration } \\
\text { (\% extract) }\end{array}$} & \multicolumn{5}{|c|}{ PR (mean $\% \pm$ S.E.M) ${ }^{\mathrm{m}}$ with exposure time (hours) posttreatment } & \multirow{2}{*}{$\begin{array}{c}\text { PR } \\
(\text { mean } \pm \text { S.E.M })^{\mathrm{n}}\end{array}$} & \multirow{2}{*}{$\begin{array}{c}\text { IP } \\
(\text { mean } \pm \text { S.E.M })^{\mathrm{n}}\end{array}$} \\
\hline & $1 \mathrm{hr}$ & $2 \mathrm{hr}$ & $3 \mathrm{hr}$ & $4 \mathrm{hr}$ & $5 \mathrm{hr}$ & & \\
\hline 25 & $\begin{array}{c}55.00 \pm 5.00^{b} \\
(0.45)\end{array}$ & $\begin{array}{c}70.00 \pm 5.77^{\mathrm{ab}} \\
(0.30)\end{array}$ & $\begin{array}{c}55.00 \pm 9.57^{b} \\
(0.45)\end{array}$ & $\begin{array}{c}65.00 \pm 9.57^{\mathrm{bc}} \\
(0.35)\end{array}$ & $\begin{array}{c}65.00 \pm 5.00^{\mathrm{ab}} \\
(0.35)\end{array}$ & $62.00 \pm 3.00^{b c}$ & $0.38 \pm 0.0670^{\mathrm{ab}}$ \\
\hline 50 & $\begin{array}{c}60.00 \pm 8.16^{\mathrm{b}} \\
(0.40)\end{array}$ & $\begin{array}{c}55.00 \pm 5.00^{\mathrm{b}} \\
(0.45)\end{array}$ & $\begin{array}{c}50.00 \pm 5.77^{\mathrm{b}} \\
(0.50)\end{array}$ & $\begin{array}{c}40.00 \pm 0.00^{c} \\
(0.60)\end{array}$ & $\begin{array}{c}50.00 \pm 5.77^{\mathrm{b}} \\
(0.50)\end{array}$ & $51.00 \pm 3.32^{\mathrm{c}}$ & $0.49 \pm 0.0332^{\mathrm{a}}$ \\
\hline 75 & $\begin{array}{c}75.00 \pm 5.00^{\mathrm{ab}} \\
(0.25)\end{array}$ & $\begin{array}{c}70.00 \pm 5.77^{\mathrm{ab}} \\
(0.30)\end{array}$ & $\begin{array}{c}85.00 \pm 5.0^{\mathrm{ab}} \\
(0.15)\end{array}$ & $\begin{array}{c}70.00 \pm 5.77^{\mathrm{abc}} \\
(0.30)\end{array}$ & $\begin{array}{c}70.00 \pm 5.77^{\mathrm{ab}} \\
(0.30)\end{array}$ & $74.00 \pm 2.92^{\mathrm{b}}$ & $0.26 \pm 0.0292^{b}$ \\
\hline 100 & $\begin{array}{c}95.00 \pm 5.00^{\mathrm{a}} \\
(0.05)\end{array}$ & $\begin{array}{c}90.00 \pm 5.77^{\mathrm{a}} \\
(0.10)\end{array}$ & $\begin{array}{c}95.00 \pm 5.00^{\mathrm{a}} \\
(0.05)\end{array}$ & $\begin{array}{c}90.00 \pm 5.77^{\mathrm{ab}} \\
(0.10)\end{array}$ & $\begin{array}{c}85.00 \pm 5.00^{\mathrm{a}} \\
(0.15)\end{array}$ & $91.00 \pm 1.87^{\mathrm{a}}$ & $0.09 \pm 0.0187^{\mathrm{c}}$ \\
\hline Actellic & $\begin{array}{c}100.00 \pm 0.00^{\mathrm{a}} \\
(0.00)\end{array}$ & $\begin{array}{c}95.00 \pm 5.00^{\mathrm{a}} \\
(0.05)\end{array}$ & $\begin{array}{c}100.0 \pm 0.00^{\mathrm{a}} \\
(0.00)\end{array}$ & $\begin{array}{c}100.0 \pm 0.00^{\mathrm{a}} \\
(0.00)\end{array}$ & $\begin{array}{c}95.00 \pm 5.00^{\mathrm{a}} \\
(0.05)\end{array}$ & $98.00 \pm 1.22^{\mathrm{a}}$ & $0.02 \pm 0.0122^{c}$ \\
\hline
\end{tabular}

Values followed by the same superscript within the same column are not significantly different $(p>0.005)$ determined by one-way ANOVA followed by Turkey's test. ${ }^{\mathrm{m}}$ Values were means based on four extract concentrations, four replicates $(n=4) .{ }^{\mathrm{n}}$ Values were means obtained over the 5-hour test duration $(n=5)$. Figures in parenthesis indicate the repellency index (IP $<1$ for repellency, IP $=1$ for neutral, and IP $>1$ for attractant).

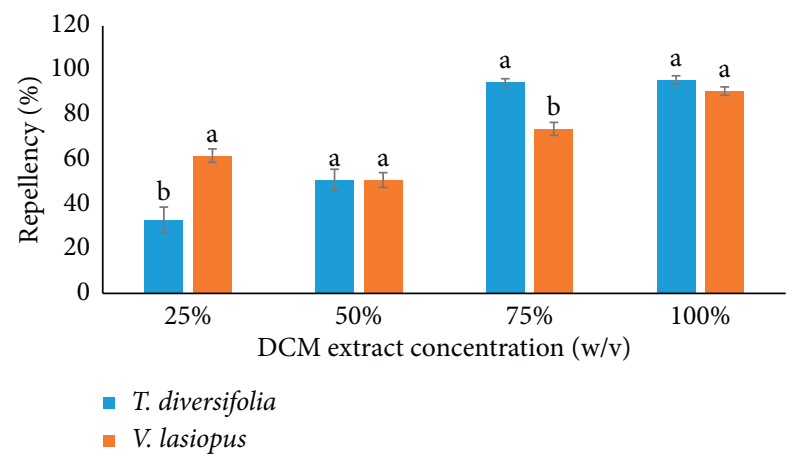

FIGURE 1: Comparison of the repellent activities (percent repellency) of the DCM leaf extracts of T. diversifolia and (V) lasiopus against $S$. zeamais. Bar graphs with different superscripts within the same concentration are significantly different by unpaired Student's test $(p \leq 0.005)$.

statistical difference in the repellent activities of the two plant extracts at the dose level of 50 and $100 \%(p>0.005)$. Both plant extracts had equal mean weevil repellency of $51 \%$ at dose of $50 \%$ (Figure 1).

3.3. Repellent Activity of Ethyl Acetate Leaf Extracts of $T$. diversifolia and $V$. lasiopus against $S$. zeamais. Generally, this study clearly showed that the repulsion of weevils by ethyl acetate leaf extracts of $T$. diversifolia and $V$. lasiopus advanced with increase in the extract concentration (Table 6). The repellent activities of the two plant extracts were independent of the duration of exposure to weevils. All the $T$. diversifolia extract concentrations (25\%, $50 \%, 75 \%$, and $100 \%$ ) caused repellent activities of above $40 \%$ within the first hour of exposure to weevils (Table 6). However, at the least extract concentration level of $25 \%$, the repellent activity gradually reduced with exposure time to $25.00 \%$ by the end of the experimental period (Table 6).

It was also evident that only the extract dose of $100 \%$ exhibited a repellent effect not statistically different from that caused by Actellic after a short time (1 hour) of exposure to weevils ( $p>0.005$; Table 6$)$. The effectiveness of the T. diversifolia extract doses of $50 \%$ and $75 \%$ were comparable to each other, while the repellency caused by the dose of $25 \%$ was significantly different from the rest of treatments after such a short period of exposure to weevils ( $p \leq 0.005$; Table 6). In the second, third, and fourth hours after exposure to weevils, the T. diversifolia doses of 25 and $50 \%$ showed comparable effects while doses of 75 and $100 \%$ similarly showed comparable effects to each other as well as to the effects caused by the conventional pesticide, Actellic ( $p>0.005$; Table 6). All the extract concentrations showed statistically similar effects during the last hour of the test period ( $p>0.005$; Table 6$)$.

On the other hand, the ethyl acetate leaf extract of $V$. lasiopus also showed remarkable repellent effects against maize weevils. The $V$. lasiopus extract concentration of $100 \%$ manifested the highest repellency (90\%) after the second, third, and fourth hours of exposure to weevil. The lowest repellency of only $10 \%$ was manifested by the $V$. lasiopus extract concentration of $25 \%$ at the last hour of the experiment period (Table 7 ).

The V. lasiopus extract concentrations of $25 \%$ and $50 \%$ induced comparable repellent effects on $S$. zeamais throughout the test period ( $p>0.05$; Table 7 ). None of the $V$. lasiopus extract concentrations achieved repellent effect comparable to the effect caused by the reference pesticide, 
TABLE 6: Repellent activity of ethyl acetate leaf extracts of T. diversifolia against S. zeamais.

\begin{tabular}{|c|c|c|c|c|c|c|c|}
\hline \multirow{2}{*}{$\begin{array}{l}\text { Concentration } \\
\text { (\% extract) }\end{array}$} & \multicolumn{5}{|c|}{ PR $\left(\right.$ mean $\% \pm$ S.E.M) ${ }^{\mathrm{m}}$ with exposure time (hours) posttreatment } & \multirow{2}{*}{$\begin{array}{c}\text { PR } \\
(\text { mean } \pm \text { S.E.M })^{n}\end{array}$} & \multirow{2}{*}{$\begin{array}{c}\text { IP } \\
(\text { mean } \pm \text { S.E.M })^{\mathrm{n}}\end{array}$} \\
\hline & $1 \mathrm{hr}$ & $2 \mathrm{hr}$ & $3 \mathrm{hr}$ & $4 \mathrm{hr}$ & $5 \mathrm{hr}$ & & \\
\hline 25 & $\begin{array}{c}40.00 \pm 0.00^{c} \\
(0.60)\end{array}$ & $\begin{array}{c}45.00 \pm 9.57^{\mathrm{b}} \\
(0.55)\end{array}$ & $\begin{array}{l}35.00 \pm 5.00^{\mathrm{b}} \\
(0.65)\end{array}$ & $\begin{array}{c}30.00 \pm 5.77^{\mathrm{b}} \\
(0.70)\end{array}$ & $\begin{array}{c}25.00 \pm 5.00^{\mathrm{b}} \\
(0.75)\end{array}$ & $35.00 \pm 3.54^{\mathrm{b}}$ & $0.65 \pm 0.0354^{\mathrm{a}}$ \\
\hline 50 & $\begin{array}{c}65.00 \pm 5.00^{\mathrm{b}} \\
(0.35)\end{array}$ & $\begin{array}{c}50.00 \pm 5.77^{\mathrm{b}} \\
(0.50)\end{array}$ & $\begin{array}{c}50.00 \pm 5.77^{\mathrm{b}} \\
(0.50)\end{array}$ & $\begin{array}{c}45.00 \pm 5.00^{\mathrm{b}} \\
(0.55)\end{array}$ & $\begin{array}{c}65.00 \pm 5.00^{\mathrm{a}} \\
(0.35)\end{array}$ & $55.00 \pm 4.18^{\mathrm{b}}$ & $0.45 \pm 0.0418^{\mathrm{a}}$ \\
\hline 75 & $\begin{array}{c}65.00 \pm 5.00^{\mathrm{b}} \\
\quad(0.25)\end{array}$ & $\begin{array}{c}95.00 \pm 5.00^{\mathrm{a}} \\
(0.05)\end{array}$ & $\begin{array}{c}90.00 \pm 5.77^{\mathrm{a}} \\
(0.10)\end{array}$ & $\begin{array}{c}85.00 \pm 9.57^{\mathrm{a}} \\
(0.15)\end{array}$ & $\begin{array}{c}95.00 \pm 5.00^{\mathrm{a}} \\
(0.05)\end{array}$ & $86.00 \pm 5.57^{\mathrm{a}}$ & $0.14 \pm 0.0557^{\mathrm{b}}$ \\
\hline 100 & $\begin{array}{c}90.00 \pm 5.77^{\mathrm{a}} \\
(0.10)\end{array}$ & $\begin{array}{c}85.00 \pm 5.00^{\mathrm{a}} \\
(0.15)\end{array}$ & $\begin{array}{c}95.00 \pm 5.00^{\mathrm{a}} \\
(0.05)\end{array}$ & $\begin{array}{c}95.00 \pm 5.00^{\mathrm{a}} \\
(0.05)\end{array}$ & $\begin{array}{c}95.00 \pm 5.00^{\mathrm{a}} \\
(0.05)\end{array}$ & $92.00 \pm 2.00^{\mathrm{a}}$ & $0.08 \pm 0.0200^{\mathrm{b}}$ \\
\hline Actellic & $\begin{array}{c}100.00 \pm 0.00^{\mathrm{a}} \\
(0.00)\end{array}$ & $\begin{array}{c}95.00 \pm 5.00^{\mathrm{a}} \\
(0.05)\end{array}$ & $\begin{array}{c}100.0 \pm 0.00^{\mathrm{a}} \\
(0.00)\end{array}$ & $\begin{array}{c}100.0 \pm 0.00^{\mathrm{a}} \\
(0.00)\end{array}$ & $\begin{array}{c}95.00 \pm 5.00^{\mathrm{a}} \\
(0.05)\end{array}$ & $98.00 \pm 1.22^{\mathrm{a}}$ & $0.02 \pm 0.0122^{\mathrm{b}}$ \\
\hline
\end{tabular}

Values followed by the same superscript within the same column are not significantly different $(p>0.005)$ determined by one-way ANOVA followed by Turkey's test. ${ }^{\mathrm{m}}$ Values were means based on four extract concentrations, four replicates $(n=4) .{ }^{\mathrm{n}}$ Values were means obtained over the 5-hour test duration $(n=5)$. Figures in parenthesis indicate the repellency index (IP $<1$ for repellency, IP $=1$ for neutral, and IP $>1$ for attractant).

TABLE 7: Repellent activity of ethyl acetate leaf extracts of $V$. lasiopus against S. zeamais.

\begin{tabular}{|c|c|c|c|c|c|c|c|}
\hline \multirow{2}{*}{$\begin{array}{l}\text { Concentration } \\
\text { (\% extract) }\end{array}$} & \multicolumn{5}{|c|}{ PR (mean $\% \pm$ S.E.M) ${ }^{\mathrm{m}}$ with exposure time (hours) posttreatment } & \multirow{2}{*}{$\begin{array}{c}\text { PR } \\
(\text { mean } \pm \text { S.E.M })^{\mathrm{n}}\end{array}$} & \multirow{2}{*}{$\begin{array}{c}\text { IP } \\
(\text { mean } \pm \text { S.E.M })^{\mathrm{n}}\end{array}$} \\
\hline & $1 \mathrm{hr}$ & $2 \mathrm{hr}$ & $3 \mathrm{hr}$ & $4 \mathrm{hr}$ & $5 \mathrm{hr}$ & & \\
\hline 25 & $\begin{array}{c}45.00 \pm 5.00^{\mathrm{bc}} \\
(0.55)\end{array}$ & $\begin{array}{c}30.00 \pm 5.77^{\mathrm{c}} \\
(0.70)\end{array}$ & $\begin{array}{c}30.00 \pm 5.77^{\mathrm{b}} \\
(0.70)\end{array}$ & $\begin{array}{c}15.00 \pm 5.00^{c} \\
(0.85)\end{array}$ & $\begin{array}{c}10.00 \pm 5.77^{\mathrm{c}} \\
(0.9)\end{array}$ & $26.00 \pm 6.20^{c}$ & $0.74 \pm 0.0620^{\mathrm{a}}$ \\
\hline 50 & $\begin{array}{c}30.00 \pm 5.77^{\mathrm{c}} \\
(0.7)\end{array}$ & $\begin{array}{c}45.00 \pm 5.00^{\mathrm{bc}} \\
(0.55)\end{array}$ & $\begin{array}{c}25.00 \pm 5.00^{\mathrm{b}} \\
(0.75)\end{array}$ & $\begin{array}{c}20.00 \pm 8.16^{\mathrm{c}} \\
(0.80)\end{array}$ & $\begin{array}{c}35.00 \pm 5.00^{\mathrm{bc}} \\
(0.65)\end{array}$ & $31.00 \pm 4.30^{\mathrm{c}}$ & $0.69 \pm 0.0430^{\mathrm{a}}$ \\
\hline 75 & $\begin{array}{c}65.00 \pm 5.00^{b} \\
(0.35)\end{array}$ & $\begin{array}{c}65.00 \pm 5.00^{\mathrm{ab}} \\
(0.35)\end{array}$ & $\begin{array}{c}50.00 \pm 5.77^{\mathrm{b}} \\
(0.50)\end{array}$ & $\begin{array}{c}60.00 \pm 0.00^{\mathrm{b}} \\
(0.40)\end{array}$ & $\begin{array}{c}75.00 \pm 5.00^{\mathrm{a}} \\
(0.25)\end{array}$ & $63.00 \pm 4.06^{\mathrm{b}}$ & $0.37 \pm 0.0406^{\mathrm{b}}$ \\
\hline 100 & $\begin{array}{c}70.00 \pm 5.77^{\mathrm{b}} \\
(0.30)\end{array}$ & $\begin{array}{c}90.00 \pm 5.77^{\mathrm{a}} \\
(0.10)\end{array}$ & $\begin{array}{c}90.00 \pm 5.77^{\mathrm{a}} \\
(0.10)\end{array}$ & $\begin{array}{c}90.00 \pm 5.77^{\mathrm{ab}} \\
(0.10)\end{array}$ & $\begin{array}{c}65.00 \pm 5.00^{\mathrm{ab}} \\
(0.35)\end{array}$ & $81.00 \pm 5.57^{\mathrm{ab}}$ & $0.19 \pm 0.0557^{b c}$ \\
\hline Actellic & $\begin{array}{c}100.00 \pm 0.00^{\mathrm{a}} \\
(0.00)\end{array}$ & $\begin{array}{c}95.00 \pm 5.00^{\mathrm{a}} \\
(0.05)\end{array}$ & $\begin{array}{c}100.0 \pm 0.00^{\mathrm{a}} \\
(0.00)\end{array}$ & $\begin{array}{c}100.0 \pm 0.00^{\mathrm{a}} \\
(0.00)\end{array}$ & $\begin{array}{c}95.00 \pm 5.00^{\mathrm{a}} \\
(0.05)\end{array}$ & $98.00 \pm 1.22^{\mathrm{a}}$ & $0.02 \pm 0.0122^{c}$ \\
\hline
\end{tabular}

Values followed by the same superscript within the same column are not significantly different $(p>0.005)$ determined by one-way ANOVA followed by Turkey's test. ${ }^{\mathrm{m}}$ Values were means based on four extract concentrations, four replicates $(n=4) .{ }^{\mathrm{n}}$ Values were means obtained over the 5 hour test duration $(n=5)$. Figures in parenthesis indicate the repellency index (IP $<1$ for repellency, IP $=1$ for neutral, and IP $>1$ for attractant).

Actellic, after 1 hour of exposure to weevils ( $p \leq 0.05$; Table 7). However, the highest test concentrations of $100 \%$ demonstrated effectiveness that was comparable $(p>0.05$; Table 7) to that of the standard pesticide throughout the rest of the experiment period. The $V$. lasiopus extract concentrations of $75 \%$ also induced repellent activity comparable to that caused by Actellic in the second and fifth hours of the test periods ( $p>0.05$; Table 7$)$.

On average, it was observed that only the $V$. lasiopus extract dose of $100 \%$ exhibited effectiveness with repellency index value of 0.19 that was not significantly different from that portrayed by the positive control, Actellic (IP 0.02) $(p>0.05$; Table 7$)$.

The comparative contrast between ethyl acetate extracts of $T$. diversifolia and $V$. lasiopus indicated that the $T$. diversifolia extract generally manifested the strongest weevil repelling potential (Figure 2). The $T$. diversifolia extract doses of 50 and $75 \%$ showed significantly more repellent abilities as compared to the $V$. lasiopus extract $(p<0.005$; Figure 2$)$. However, the $T$. diversifolia and $V$. lasiopus extract doses of 25 and $100 \%$ manifested statistically similar effectiveness in repellency $(p>0.005$; Figure 2).

\section{Discussion}

This study was designed to evaluate repellent properties of crude organic extracts of $T$. diversifolia and $V$. lasiopus on $S$. zeamais. All the studied organic leaf extracts of $T$. diversifolia and $V$. lasiopus demonstrated potent repellent potential on S. zeamais. By the end of $5 \mathrm{~h}$ of the test period, it was evident that all the test samples turned out to simply discourage S. zeamais from attacking the grains made them craw away from the extract-treated areas. Most of the insects stayed on the untreated areas of Petri dishes and evaded the extract-treated areas. The extracts were able to induce insect 


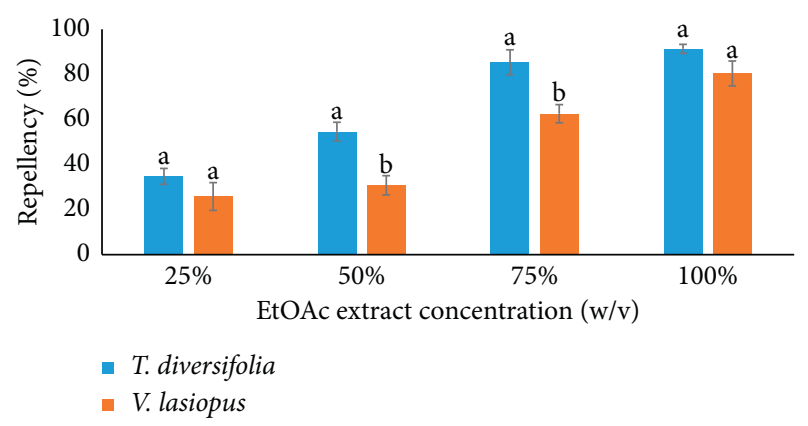

FIgURE 2: Comparison of the repellent activities (percent repellency) of the ethyl acetate leaf extracts of $T$. diversifolia and $(V)$ lasiopus against $S$. zeamais. Bar graphs with different superscripts within the same concentration are significantly different by unpaired Student's test $(p \leq 0.005)$.

repellency of between 10 and $100 \%$ within 5 hours of the experimental period.

With a minimum of $80 \%$ pesticidal action required for test substance to be considered successful [28], both of these plant organic leaf extracts largely exhibited potential repellent actions against the weevils. The repellent index value of all the organic leaf extracts of $T$. diversifolia and $V$. lasiopus against $S$. zeamais adults was lower than 1 , and thus, they were classified as insect repellents and not attractants. The present finding correlated with that of other plant extracts such as Aframomum melegueta and Zingiber officinale which repelled adults S. zeamais [29-31].

Consistent with these findings, the hexane-ethyl acetate extracts of C. capitatum exhibited 90\%-98\% repellency activities against stored grain pests $S$. oryzae, $R$. dominica, and $T$. castaneum. Acetone seed extract of Aphanamixis polystachya showed $100 \%$ repellent effects on red flour beetles [32]. Pretheep-Kumar et al. [33] found a maximum of $91.2 \%$ of repellency with an extract of protein enriched bean flour on weevils, S. oryzae, after $48 \mathrm{~h}$ of the test period.

The high insect repellent results seen in this study are also supported by Boateng and Kusi [34] who showed that $J$. curcas seed extracts could repel up to $95 \%$ of the C. maculatus and D. basalis. Likewise, Yoon and Ahnjo [35] also reported that caraway and grapefruit successfully repelled weevils at such high rates. Acetone seed extract of Aphanamixis polystachya showed $100 \%$ repellent effects on red flour beetles [32]. The ethanol extracts of Urtica dioica and Taraxacum officinale, respectively, showed $99.4 \%$ and 98.8\% repellency, after $48 \mathrm{~h}$ of the study period [36].

A number of other plants have been demonstrated to exhibit good repellent activities against $S$. zeamais. Ishii et al. [37] reported high susceptibility of S. zeamais to extracts and essential oils of common spices. Members of the Alliaceae family such as garlic have previously been reported to possess repellent properties on $S$. zeamais $[11,38,39]$. The extracts of $M$. nodosa, $O$. surinamensis, and $L$. aurea also showed repellent effects on S. zeamais [40].

The present findings correlated with repellency effects of diethyl ether extracts of $A$. melegueta and $Z$. officinale on $S$. zeamais [29]. Trivedi et al. [41] further demonstrated repellent activities of essential oils of cinnamon, clove, rosemary, bergamot, and Japanese mint against pulse beetle (Callosobruchus chinensis). Many other related studies have also documented repellent potential of various plants against other postharvest pests [42-44].

In contrast, Tavares and Vendramim [45] reported a lack of repellent activity of insecticidal extracts of C. ambrosioides on S. zeamais. Furthermore, contrary to the findings of the present study, [46] previously achieved very low repellent activities of herbal extracts of $T$. officinale (100\%) and $U$. dioica (100\%) against bean weevils. These findings do not agree with the results observed in the present work, in which all the studied extracts showed remarkable repellent activities on the target insect. This is probably due to performance of extracts derived from plants of different families from the presently studied extracts.

A free choice (area preference) bioassay model was used in this study for it is easily applicable and reliable. Similar laboratory tests were carried out using extracts of 13 plants to assess their repellent properties against the banana weevil [46]. A free choice bioassay system was also used to evaluate repellency effects of extracts and fractions from leaves of C. capitatum against three major stored grain insect pests, namely, S. oryzae, $R$. dominica, and T. castaneum [47].

The extract concentration ranges used in this study were within the dose ranges used by Ofuya et al. [48], Ouko et al. $[11]$, and Acero $[49,50]$. The works of Acero [49] and Acero [50] used extract concentrations of $25 \%, 50 \%$, and $75 \%$ in evaluating the pesticidal properties of $A$. heterophyllus and C. odorata against a closely similar weevil, S. oryzae. The study of Ouko et al. (2017)[11] also used similar extract concentration levels in determining repellency effects of A. sativum and $\mathrm{O}$. basilicum on maize weevils.

The levels of repulsion of target insects in the present study were generally proportional to the extract concentrations. An increase in extract concentration resulted in an increase in the repulsion of $S$. zeamais. This could be due to the increase in bioactive components as the concentration of the extract increased. There was no appropriate concentration of the active principle(s) at the lower extract dose levels. It is also likely that at a lower dose, there is simply not a sufficient concentration of the active principle(s).

That the effectiveness of the extracts was dependent on extract concentrations is in agreement with earlier research studies of Chaieb et al. [51], Kafle and Shih [52], CortésRojas et al. [53], and Nattudurai et al. [54] among others. In a related study, Marimuthu [55] indicated plant extracts distilled from C. citrates, C. zeylanicum, $R$. officinalis, and $Z$. officinale had promising dose-dependent repellent properties against Culex tritaeniorhynchus and Anopheles subpictus. Furthermore, the nonpolar and oil leaf extracts of Ocimum viride also offered a dose-dependent repellent potential against Aedes aegypti [56]

Interestingly, the effectiveness of $V$. lasiopus extracts at low concentrations (25 and 50\%) was not significantly different from the effects caused by high extract doses (75 and $100 \%$ ) as well as the positive control, Actellic, during the first 2 hours of the test period. This may be due to the fact that, even at low extract concentration, the combination of 
repellent compounds was also in the appropriate proportional mixture to repel the target insects.

This observation was similar to the previous results for other plant extracts against different insect pests including S. zeamais, T. casteneum, and S. oryzae $[57,58]$. Similarly, the organic extracts of Eucalyptus globulus, Citrullus colocynthis, and O. basilicum have also shown strong repellency against S. oryzae, C. maculatus, and T. casteneum at remarkably lower concentrations $[59,60]$.

The findings of this study demonstrated no trend with exposure time. In fact, high repellent ratings were scantly noted at both the initial and final hours of the experiment. This is could be due to a possibility that $S$. zeamais was equally sensitive to the extracts' odor even at low concentration. Other studies have also indicated such trends where repellent activities of plant extracts on insects were independent of exposure time [11]. On the contrary, Mobki et al. [58] reported that repellent activity of garlic extract to S. zeamais increased with duration of exposure. However, where an increase in repellency activities was noted for the first 3 hours of the test period followed by decrease in repellency is interesting. This decrease may be caused by evaporation of the active volatile compound(s).

It was evident that repellent activities were more pronounced for $T$. diversifolia than $V$. lasiopus extracts. This variation could be attributed to unequal distribution of chemical constituents within these plant species. The high repulsive activity of $T$. diversifolia extracts is an indication of higher concentration of phytochemicals with repellent activities as compared to V. lasiopus extracts. After all, the chemical variations in plant extracts composition are rather common even within the same species. Mainly, this depends on the type of genotype, plant organ, harvest, region, season, climatic conditions, and plant nutritional status [61, 62].

The contrasts between solvents extractives of the two plants indicated DCM extract as being significantly less potent than ethyl acetate extracts. The higher effectiveness exhibited by EtOAc leaf extracts indicated that this solvent captured more actively repellent compounds within the extract than the DCM. This finding mirrors the earlier report that EtOAc extract of Citrullus colocynthis and Gnidia kaussiana (Thymeleaceae) exhibited a higher repellent activity against cowpea weevil than hexane and methanol extracts [60].

The plant extracts acted as repellents by driving the insects away due to their smell or taste. Arthropods such as insects and mites will tend to evade areas with pungent odor $[49,50]$. The repulsion of weevils by these extracts was possibly through stimulation of olfactory receptors [63]. They have several olfactory receptor cells (ORCs) in their antennae [64]. The ORCs have a coded pattern of behavior for the specific quality and quantity of semiochemicals in different complex mixtures present in their environment.

In response to an odor substance emitted into insects' environment, chemical message is decoded and integrated into the olfactory centers of the central nervous system (CNS) [65]. Hydrocarbons especially monoterpenes and oxygenated compounds such as phenols and esters determine distinctive odor of plants and hence the plants' repellent effect on insects $[39,42,66]$. To produce an odor sensation, the phytochemical substance must be volatile and its molecules must come into contact with the olfactory end organ in the insect pest [67].

This ultimately causes olfactory-induced changes in the behavior of the insects, which is of considerable importance in relation to the mechanism of insect attractancy and repellency [65]. A similar mechanism of action could have been used by the phytochemicals in $T$. diversifolia and $V$. lasiopus leaf extracts to induce repulsion activity of S. zeamais.

The repellent phytochemicals could also have acted by interfering with the perception of host-attractant signals. These phytochemicals could have induced excitement of receptors responsible for an opposite or competing behavior rather than food-attractancy behavior [64]. This resulted to switching of the sensory message from attraction to repulsion. Several different receptor systems were hence activated so that the normal and meaningful sensory information was "jammed" by the enhanced repellent effect and exciting the repellent (noxious substance/phytocompound) receptors $[49,64,65]$.

The observed repellent activity in the present study could partly be attributed to the presence of plant volatile bioactive constituents, which are well-known repellents of insects by acting in the vapour form on the olfactory receptors $[64,68]$. This has been partly due to the lack of any secure correlation between the odors of phytochemical and the chemical constitution, reactivity, physical shapes, or electrical properties of the odorous molecules [64]. Although much of explanation for repellency is generally agreed, there has been no accepted theory of the triggering process by which the odorous molecule beyond this, towards initiation and discharge of the olfactory nerve [64]. However, the mechanism of interaction of the olfactory receptors and the phytochemicals is still obscure.

The GC-MS analysis revealed a range of volatile phytochemical compounds in the tested plant extracts including alkaloids, terpenoids, fatty acids, phytosterols, and benzaldehyde, among others. These phytochemical compounds could be responsible for the observed repellency activities against the S. zeamais. The concentrations of the major repellant terpenoids observed in $T$. diversifolia and $V$. lasiopus organic extracts are consistent with the demonstrated properties of these plant as an insect repellent.

Terpenes are widely linked to insect repellent or attractant properties. The presence of terpenes is speculated to be associated with fragrance and repellent activities of essential oils. Several studies have also indicated terpenoids as arthropod-repellent compounds [42]. However, terpenes from ponderosa pine bark have been characterized as attractants to bark beetle, and Ips confusus and isothiocyanates from the seeds of crucifera are attractants to insects seeking food and site for oviposition [69].

The repellent activities of $T$. diversifolia and $V$. lasiopus extracts could have been due presence of monoterpenes. Monoterpenes such as eugenol, limonene, camphor, and thymol commonly found in basil have strong repellent activities against insects [70]. Odalo et al. [71] also found out 
monoterpenes components of basil (labiate) as effective repellents against $A$. gambiae (Diptera).

Widdrol is an odorous phytocompound, whose presence in the ethyl acetate leaf extract of $T$. diversifolia is likely to have contributed to the strong odor of the plant extracts. It is such smells in the extracts that are thought to drive the insects away especially because insects will always tend to evade places with such pungent odors [50]. However, it still remains difficult to make a precise association of widdrol with the repellent activities of plant extracts [72].

The presence of vanillin (a phenolic aldehyde) in the studied extracts could also have contributed to the observed repellency activities. Vanilla extract has been reported as significant insect repellent due to its distinct aroma and flavor [73]. It works well in safeguarding homes and body skin against insects such as mosquitoes, flies, and gnats [74, 75]. Vanilla extract is usually effective as an insect repellent for about half an hour. Hence, it requires reapplication more especially when exposed to very high temperatures which may cause it to evaporate quickly or in cases of being diluted with water elements such as rain [75].

The GC-MS analysis revealed that the organic leaf extracts of $T$. diversifolia and $V$. lasiopus contain odorous oleic and linoleic acids, which could also be associated with their repellent properties. Arthropods are known to release oleic and linoleic acids upon death usually referred to as "smell of death." The smell of these compounds is believed to repel other insects, thereby keeping them away from approaching their death zone. A previous study by Ramsewak et al. [76] attributed the botanical repellent effects on Aedes aegypti, Helicoverpa zea, Lymantria dispar, Orgyia leucostigma, and Malacosoma disstria to the strong smell of oleic and linoleic acids.

The repellent activities of the extracts on adult weevils in the present study could also be linked to the presence of $\alpha$-bulnesene in the organic leaf extracts of $T$. diversifolia and $V$. lasiopus. According to Gokulakrishnan et al. [77], $\alpha$-bulnesene extracted from Pogostemon cablin exhibits repellent activities against various urban ant species. Similarly, the presence of $\alpha$-bulnesene in $P$. cablin was associated with the plant's repellent activities against selected important vectors of mosquitoes including Aedes aegypti, Anopheles stephensi, and Culex quinquefasciatus [78].

The repellency of the organic leaf extracts of $T$. diversifolia and $V$. lasiopus against S. zeamais may be explained by the revealed presence of benzaldehyde in these extracts. Benzaldehyde is also the main chemical compound in $M$. nodosa, which was reported to be the cause of moderate repellency against $S$. zeamais, $O$. surinamensis, and Amblyomma cajennense [40, 79, 80].

Additionally, benzaldehyde was also extracted from Tanaecium nocturnum (Bignoneaceae), which caused repellency to Sitophilus oryzae (Coleoptera: Curculionidae), Rhyzopertha dominica (Coleoptera: Bostrichidae), and T. castaneum [81]. Furthermore, benzaldehyde has been found to be lethal on $S$. zeamais and Tenebrio molitor (Coleoptera: Tenebrionidae), confirming its bioactivity against stored grain pests [82].

The repellent properties of these extracts could also be attributed to specific compounds among the many that GC-MS analysis revealed in this study. However, synergistic or additive effects as a result of combination and interaction between phytochemicals cannot be ignored [83]. Furthermore, the repellent activities of the plant volatiles may not be limited only to its major constituents; it could also be due to some minor constituents or a synergistic effect of several constituents [47].

Actellic ${ }^{\circledR} 25 \mathrm{EC}$, is a broad spectrum insecticide. It is conventionally used for the control of storage pests in bulk-stored grains, bagged grains, and storage surfaces. It is also effectively used for the control of insect pests in pineapples, citrus, bananas, potatoes, and vegetables. It contains $250 \mathrm{~g} / \mathrm{ml}$ pirimiphosmethyl which is taken by the insect through its respiratory system and affects the pests through its repellence effects. Although Actellic is actually a contact insecticide, it contains permethrin which was recently studied and suggested as an insecticide as well as an insect repellent [84-86]. In fact, in the US, Actellic is registered as both repellent and insecticide $[84,85]$. It is worth noting that on average, after a $5 \mathrm{~h}$ test period, all extracts of $T$. diversifolia and $V$. lasiopus produced appreciable repellent activities against weevils, which compare well with the standard chemical Actellic. This suggests a possible mimicry of Actellic mode of action by active phytochemicals in the studied crude extracts in repelling the weevils. In conclusion, the findings of this study evidently show that the organic leaf extracts of $T$. diversifolia and $V$. lasiopus can be used as an effective repellent agent against $S$. zeamais on stored maize grains.

\section{Data Availability}

No data were used to support this study.

\section{Conflicts of Interest}

The authors declare no conflicts of interest.

\section{Authors' Contributions}

Stephen Gitahi, Mathew Piero Ngugi, David Mburu, and Alex Machocho conceived and designed the experiments and contributed reagents, materials, and analysis tools. They also performed the experiments, analyzed and interpreted the data, and wrote the paper.

\section{Acknowledgments}

The authors wish to thank Kenyatta University for availing insects rearing facility and laboratories for experimentation. The authors would also like to express their gratitude to the International Centre of Insect Physiology and Ecology (ICIPE) for allowing them use their laboratory to carry out GC-MS analysis of the plant extracts. The authors thank to the entire staff of the Biochemistry, Microbiology, and Biotechnology department for offering them with technical assistance. This research did not receive any specific grant from funding agencies in the public, commercial, or not-for-profit sectors. 


\section{References}

[1] W. Oluoch-Kosura, Maize Farming in Kenya: Where Did it Go Wrong, IDS Institute of Development Studies, Brighton, UK, 2011.

[2] A. Olubandwa, N. J. Kathuri, D. Odero-Wanga, and W. A. Shivoga, "Challenges facing small scale maize farmers in western province of Kenya in the agricultural reform era," American Journal of Experimental Agriculture, vol. 1, no. 4, pp. 466-476, 2011.

[3] C. Parwada, T. J. Chikuvire, A. Kamota, R. Mandumbu, and K. Mutsengi, "Use of botanical pesticides in controlling Sitophilus zeamais (maize weevil) on stored Zea mays (maize) grain," Modern Concepts and Developments in Agronomy, vol. 4, 2018

[4] K. A. Vowotor, W. G. Meikle, J. N. Ayertey, and R. H. Markham, "Distribution of and association between the larger grain borer Prostephanus truncatus (horn) (Coleoptera: Bostrichidae) and the maize weevil Sitophilus zeamais: motschulsky (Coleoptera: Curculionidae) in maize stores," Journal of Stored Products Research, vol. 31, pp. 29-36, 2005.

[5] W. K. Peng and R. Morallo, "Grain storage insects," in Proceedings of the International Workshop on Rice Seed Health, International Rice Development Institute and United Nations Development Programme, Manila. Philippine, March 1988.

[6] D. S. Hill, Pest of Crops in Warmer Climates and Their Control, p. 704, Spinger Science and Business Media, Berlin, Germany, 2008.

[7] R. K. Mishra, A. Bohra, N. Kamaal et al., "Utilization of biopesticides as sustainable solutions for management of pests in legume crops: achievements and prospects," Egyptian Journal of Biological Pest Control, vol. 28, no. 1, p. 3, 2018.

[8] D. Champakaew, A. Junkum, U. Chaithong et al., "Angelica sinensis (Umbelliferae) with proven repellent properties against Aedes aegypti, the primary dengue fever vector in Thailand," Parasitology Research, vol. 114, no. 6, pp. 2187-2198, 2015.

[9] B. Liu, B. Chen, J. Zhang, P. Wang, and G. Feng, "The environmental fate of thymol, a novel botanical pesticide, in tropical agricultural soil and water," Toxicological \& Environmental Chemistry, vol. 99, no. 2, pp. 223-232, 2017.

[10] O. I. Osariyekemwen and G. Osarieme, "Repellence and toxicological activity of the root powder of an invasive alien plant, Chromolaena odorata (L.) (Asteraceae). Against Callosobruchus maculatus (fab.) (Coleoptera: chrysomelidae) uyi," Animal Research International, vol. 13, no. 3, pp. 2510-2517, 2016.

[11] R. O. Ouko, S. C. Koech, W. M. Arika et al., "Bioefficacy of organic extracts of A. sativum against S. zeamais (Coleoptera; Dryophthoridae)," Biological Systems, vol. 6, p. 174, 2017.

[12] E. F. Nkechi, O. G. Ejike, N. J. Ihuoma et al., "Effects of aqueous and oil leaf extracts of Pterocarpus santalinoides on the maize weevil, Sitophilus zeamais, pest of stored maize grains," African Journal of Agricultural Research, vol. 13, pp. 617-626, 2018.

[13] W. Linthoingambi and S. S. Mutum, “Antimicrobial activities of different solvent extracts of Tithonia diversifolia (Hemsely) A. Gray," Asian Journal of Plant Science and Research, vol. 3, no. 50-54, pp. 2249-7412, 2013.

[14] C. O. Adedire, R. O. Akinkurolere, and O. O. Ajayi, "Susceptiblity of some maize cultivars in Nigeria to infestation and damage by maize weevil, Sitophilus zeamais (Motsch.)
(Coleoptera: Curculionidae)," Nigerian Journal of Entomology, vol. 28, pp. 55-63, 2011.

[15] J. M. Githinji, T. Maitho, and J. M. Mbaria, "Antifleas activity and safety of tithoniadiversifolia and sennadidymobotrya, extracts," Journal of Pharmacy and Pharmacology Research, vol. 2, pp. 78-92, 2018.

[16] C. A. Shisanya, "Determinants of sustainable utilization of plant resources in the former kakamega district, Kenya," Organization for Social Science Research in Eastern and Southern Addis Ababa, vol. 20, pp. 62-63, 2011.

[17] J. N. Mwangi, H. S. Ozwara, and M. M. Gicheru, "Epidemiology of Tunga penetrans infection in selected areas in Kiharu constituency, murang'a, Kenya," Tropical Diseases, Travel Medicine and Vaccines, vol. 1, pp. 13-15, 2015.

[18] B. N. Irungu, G. M. Rukunga, G. M. Mungai, and C. N. Muthaura, "In vitro antiplasmodial and cytotoxicity activities of 14 medicinal plants from Kenya," South African Journal of Botany, vol. 73, no. 2, pp. 204-207, 2007.

[19] F. W. Muregi, A. Ishih, T. Miyase et al., "Antimalarial activity of methanolic extracts from plants used in Kenyan ethnomedicine and their interactions with chloroquine (CQ) against a CQ-tolerant rodent parasite, in mice," Journal of Ethnopharmacology, vol. 111, no. 1, pp. 190-195, 2007.

[20] P. G. Kareru, A. N. Gachanja, J. M. Keriko, and G. M. Kenji, "Antimicrobial activity of some medicinal plants used by herbalists in eastern province, Kenya," The African Journal of Traditional, Complementary And Alternative Medicines, vol. 5, no. 1, pp. 51-55, 2008.

[21] W. Wanzala, "Potential of traditional knowledge of plants in the management of arthropods in livestock industry with focus on (Acari) ticks," Evidence-Based Complementary and Alternative Medicine, vol. 2017, Article ID 8647919, 33 pages, 2017.

[22] R. K. Singh and A. K. Singh, "Efficacy of different indigenous plant products as grain protectants against Rhyzopertha dominica (Fab) on wheat," Indian Journal of Entomology, vol. 67, pp. 196-198, 2005.

[23] P. Tiwari, M. Kumar, M. Kaur, G. Kaur, and H. Kaur, "Phytochemical screening and extraction: a review," Internationale Pharmacentia Science, vol. 1, pp. 98-106, 2011.

[24] S. D. Deshmukh and M. N. Borle, "Studies on the insecticidal properties of indigenous plant products," Indian Journal of Entomology, vol. 37, no. 1, pp. 11-18, 1975.

[25] D. Obeng-Ofori, C. H. Reichmuth, A. J. Bekele, and A. Hassanali, "Toxicity and protectant potential of camphor, a major component of essential oil of Ocimum kilimandscharicum, against four stored product beetles," International Journal of Pest Management, vol. 44, no. 4, pp. 203-209, 1998.

[26] W. M. Thein, P. A. Javier, and F. A. Ceballo, "Insecticidal activity of crude plant extracts against Sitophilus spp. (Coleoptera: Curculionidae) and Callosobruchus chinensis (L.)(Coleoptera: bruchidae)," Philippine Agricultural Scientist, vol. 96, no. 2, pp. 154-162, 2013.

[27] L. S. Nerio, J. Olivero-Verbel, and E. E. Stashenko, "Repellent activity of essential oils from seven aromatic plants grown in Colombia against Sitophilus zeamais Motschulsky (Coleoptera)," Journal of Stored Products Research, vol. 45, no. 3, pp. 212-214, 2009.

[28] B. J. Kay, V. R. Swart, and E. van-der-Watt, "Evaluation and comparison of various plant extracts as repellents against Lucilia spp.” African Entomology, vol. 27, no. 1, pp. 167-177, 2019.

[29] D. A. Ukeh, M. A. Birkett, J. A. Pickett, A. S. Bowman, and A. Jennifer Mordue, "Repellent activity of alligator pepper, 
Aframomum melegueta, and ginger, Zingiber officinale, against the maize weevil, Sitophilus zeamais," Phytochemistry, vol. 70, no. 6, pp. 751-758, 2009.

[30] S. Mmbone, M. Mulaa, F. M. Wanjala, R. W. Nyukuri, and E. Cheramgoi, "Efficacy of Tagetes minuta and Tephrosia vogelii crude leaf extracts on Tetranychus urticae (Acari: tetranychidae) and Aphis fabae (Homoptera: aphididae)," African Journal of Food Science and Technology, vol. 5, no. 8, pp. 168-173, 2014.

[31] M. S. M. Ismail, H. M. Tag, and M. A. Rizk, "Acaricidal, ovicidal, and repellent effects of Tagetes patula leaf extract against," Tetranychus Urticae Koch (Acari: Tetranychidae), vol. 59, no. 2, pp. 151-159, 2019.

[32] F. A. Talukder and P. E. Howse, "Evaluation of Aphanamixis polystachya as a source of repellents, antifeedants, toxicants and protectants in storage against Tribolium castaneum (Herbst)," Journal of Stored Products Research, vol. 31, no. 1, pp. 55-61, 1995.

[33] P. Pretheep-Kumar, S. Mohan, and K. Ramaraju, "Proteinenriched pea flour extract stored milled rice against the rice weevil, Sitophilus oryzae," Journal of Insect Science, vol. 4, p. 26, 2004.

[34] B. Boateng and F. Kusi, "Toxicity of jatropha seed oil to Callosobruchus maculatus (Coleoptera: bruchidae) and its parasitoid, Dinarmus basalis (hymenoptera: pteromalidae)," Journal of Applied Science Research, vol. 4, pp. 945-951, 2008.

[35] S.-S. Yoon and S.-M. Ahnjo, "Mechanisms of amyloid- $\beta$ peptide clearance: potential therapeutic targets for alzheimer's disease," Biomolecules and Therapeutics, vol. 20, no. 3, pp. 245-255, 2012.

[36] Z. Jovanovic, M. Kostic, and Z. Popovic, "Grain protective properties of herbal extract against the bean weevil Acanthoscelides obtectus say," Industrial Crops Products, vol. 26, pp. 100-104, 2007.

[37] T. Ishii, H. Matsuzawa, and C. S. Vairappan, "Repellent activity of common spices against the rice weevil, Sitophilus zeamais Motsch (Coleoptera, Curculionidae)," Tropical Biology and Conservation, vol. 7, pp. 75-80, 2010.

[38] F.-L. Yang, F. Zhu, and C.-L. Lei, "Insecticidal activities of garlic substances against adults of grain moth, Sitotroga cerealella (Lepidoptera: gelechiidae)," Insect Science, vol. 19, no. 2, pp. 205-212, 2012.

[39] C. Karavina, R. Mandumbu, E. Zivenge, and T. Munetsi, "Use of garlic (Allium sativum) as a repellent crop to control diamondback moth (Plutella xylostella) in cabbage (Brassica oleraceae var. capitata)," Agricultural Research, vol. 52, pp. 1-7, 2014.

[40] H. A. Fouad, L. R. D. Faroni, R. C. Ribeiro, W. De S. Tavares, and F. Petacci, "5extraction and repellent activity of Lepidoploa aurea and Memora nodosa against stored grain and byproduct pests," Vie Et Milieu - Life And Environment, vol. 62 , no. 1 , p. 11, 2012.

[41] A. Trivedi, N. Nayak, and J. Kumar, "Fumigant toxicity study of different essential oils against stored grain pest Callosobruchus chinensis," Journal of Pharmacognosy and Phytochemistry, vol. 6, no. 4, pp. 1708-1711, 2017.

[42] L. S. Neiro, J. Olivero-Verbel, and E. Stashenko, "Repellent activity of essential oils: a review," Bioresource Technology, vol. 101, pp. 372-378, 2010.

[43] W. Auamcharoen, A. Chandrapatya, A. Kijjoa, and Y. Kainoh, "Toxicity and repellency activities of the crude methanol extract of Duabanga grandiflora (Lythraceae) against Sitophilus oryzae (Coleoptera: Curculionidae)," Pakistan Journal of Zoology, vol. 44, no. 1, pp. 227-232, 2012.
[44] M. C. Niroumand, M. H. Farzaei, E. K. Razkenari et al., "An evidence-based review on medicinal plants used as insecticide and insect repellent in traditional Iranian medicine," Iranian Red Crescent Medical Journal, vol. 18, no. 2, 2016.

[45] M. A. G. C. Tavares and J. D. Vendramim, "Bioatividade da erva-de-santa-maria, Chenopodium ambrosioides L., sobre Sitophilus zeamais Mots. (Coleoptera: Curculionidae)," Neotropical Entomology, vol. 34, no. 2, pp. 319-323, 2005.

[46] K. C. Emeasor, R. O. Ogbuji, and S. O. Emosairue, "Insecticidal activity of some seed powders against Callosobruchus maculatus (F.) (Coleoptera: bruchidae) on stored cowpea," Journal of Plant Diseases and Protection, vol. 112, no. 1, pp. 80-87, 2005.

[47] J. M. Adesina, A. Raghavendra, and Y. Rajashekar, "Potential use of Clerodendrum capitatum extracts and its formulation for control of three major stored product beetles," Food Quality and Safety, vol. 3, no. 3, pp. 179-185, 2019.

[48] I. O. Ofuya, C. A. Ibidapo, D. O. Moronkola et al., "Antimalarial and repellent activities of Tithonia diversifolia (Hemsl.) leaf extracts," Journal of Medicinal Plants Research, vol. 2, no. 8, pp. 171-175, 2008.

[49] L. H. Acero, "Fresh siam weed (Chromolaena odorota) leaf extract in the control of housefly (Musca domestica)," International Journal of Food Engineering, vol. 3, no. 1, pp. 56-60, 2017.

[50] L. H. Acero, "Insecticidal property of jackfruit (Artocarpus heterophyllus) peel ethanol extract against rice weevils (Sitophilus oryzae)," International Journal of Bioscience, Biochemistry and Bioinformatics, vol. 158, no. 9, pp. 158-165, 2019.

[51] K. Chaieb, H. Hajlaoui, T. Zmantar et al., "The chemical composition and biological activity of clove essential oil,Eugenia caryophyllata (Syzigium aromaticum L. Myrtaceae): a short review," Phytotherapy Research, vol. 21, no. 6, pp. 501-506, 2007.

[52] L. Kafle and C. J. Shih, "Toxicity and repellency of compounds from clove (Syzygium aromaticum) to red imported fire ants Solenopsis invicta (Hymenoptera: formicidae)," Journal of Economic Entomology, vol. 106, no. 1, pp. 131-135, 2013.

[53] D. F. Cortés-Rojas, C. R. F. de Souza, and W. P. Oliveira, "Clove (Syzygium aromaticum): a precious spice," Asian Pacific Journal of Tropical Biomedicine, vol. 4, no. 2, pp. 90-96, 2014.

[54] G. Nattudurai, S. Santiagu, G. M. Irudayaraj, B. Kathirvelu, and S. Ignacimuthu, "Entomol insecticidal and repellent activities of Toddalia asiatica (L.) lam. Extracts against three major stored product pests," Ornithol Herpetology, vol. 4, p. 2, 2015.

[55] G. Marimuthu, "Larvicidal and repellent properties of some essential oils against Culex tritaeniorhynchus Giles and Anopheles subpictus Grassi (Diptera: Culicidae)," Asian Pacific Journal of Tropical Medicine, vol. 106, p. 111, 2011.

[56] E. A. Asiamah and M. A. Botchey, "Repellent and mosquitocidal properties of smoke from oil and non-polar extracts of Ocimum viride leaf against Aedes aegyptii," Journal of Applied Sciences, vol. 19, no. 6, pp. 618-623, 2019.

[57] I. O. Udo, "Efficacy of Candlewood Zanthoxylum xanthoxyloides Lam. for the control of three product pests," M. Phil thesis, University of Ghana, Accra, Ghana, 2000.

[58] M. Mobki, S. A. Safavi, M. H. Safaralizadeh, and O. Panahi, "Toxicity and repellency of garlic (Allium sativumL.) extract grown in Iran againstTribolium castaneum(Herbst) larvae and adults," Archives of Phytopathology and Plant Protection, vol. 47, no. 1, pp. 59-68, 2014. 
[59] B. B. Mishra, S. P. Tripathi, and C. P. M. Tripathi, "Repellent effect of leaves essential oils from (Eucalyptus globulus) (Mirtaceae) and (Ocimum basilicum) (Lamiaceae) against two major stored grain insect pests of Coleopterons," Nature Science, vol. 10, no. 2, pp. 50-54, 2012.

[60] D. Kosini and E. N. Nukenine, "Bioactivity of novel botanical insecticide from Gnidia kaussiana (Thymeleaceae) against Callosobruchus maculatus (Coleoptera: chrysomelidae) in stored Vigna subterranea (Fabaceae) grains," Journal of Insect Sciences, vol. 1, no. 1, p. 17, 2017.

[61] B. Webster, S. Gezan, T. Bruce, J. Hardie, and J. Pickett, "Between plant and diurnal variation in quantities and ratios of volatile compounds emitted by Vicia faba plants," Phytochemistry, vol. 71, no. 1, pp. 81-89, 2010.

[62] W. Dhif, S. Bellili, S. Jazi, N. Bahloul, and W. Mnif, "Essential oils' chemical characterization and investigation of some biological activities: a critical review," Medicines, vol. 3, pp. 1-16, 2016.

[63] Y. Rajashekar, N. Bakthavatsalam, and T. Shivanandappa, "Botanicals as grain protectants," Psyche: A Journal Of Entomology, vol. 7, no. 4, pp. 13-17, 2012.

[64] P. Kain, S. M. Boyle, S. K. Tharadra et al., "Odour receptors and neurons for DEET and new insect repellents," Nature, vol. 502, no. 7472, pp. 507-512, 2013.

[65] T. Eisner and J. Meinwald, Chemical Ecology. The Chemistry of Biotic Interaction, pp. 161-182, National Academy Press, Washington, DC, USA, 1995.

[66] I. D. Nwachukwu and E. F. Asawalam, "Evaluation of freshly prepared juice from garlic (Allium sativum L.) as a biopesticide against the maize weevil, Sitophilus zeamais (Motsch.) (Coleoptera: Curculionidae)," Journal of Plant Protection Research, vol. 54, no. 2, pp. 132-138, 2014.

[67] S. J. Moore, "Plant-based insect repellents," in Insect Repellents Handbook, M. Debboun, S. P. Frances, and D. Strickman, Eds., vol. 2, no. 1, pp. 79-213, CRC Press, Boca Raton, FL, USA, 2014.

[68] Z. Wang, J. Song, and J. Chen, "QSAR study of mosquito repellents from terpenoid with a six-member-ring," Bioorganic and Medicinal Chemistry Letters, vol. 18, no. 9, pp. 2854-2859, 2008.

[69] P. P. Mahulikar and K. M. Chavan, Botanicals as Ecofriendly Pesticides, p. 64, New India Publishing Agency, New Delhi, India, 2007.

[70] Y. C. Yang, E. H. Lee, H. S. Lee, D. K. Lee, and Y. J. Ahn, "Repellency of aromatic medicinal plant extracts and a steam distillate to Aedes aegypti," Journal of the American Mosquito Control Association, vol. 20, no. 2, pp. 146-149, 2004.

[71] J. O. Odalo, M. O. Omolo, H. Malebo et al., "Repellency of essential oils of some plants from the Kenyan coast against Anopheles gambiae," Acta Tropica, vol. 95, no. 3, pp. 210-218, 2005.

[72] H. Jiang, J. Wang, L. Song et al., "GC $\times$ GC-TOFMS analysis of essential oils composition from leaves, twigs and seeds of cinnamomum camphora L. Presl and their insecticidal and repellent activities," Molecules, vol. 21, no. 4, p. 423, 2016.

[73] R. J. Lewis, Sax's Dangerous Properties of Industrial Materials, vol. 11, pp. 36-61, Hoboken, NJ, USA, 2004.

[74] S. Gupta and B. Sharma, "Pharmacological benefits of agomelatine and vanillin in experimental model of Huntington's disease," Pharmacology Biochemistry and Behavior, vol. 122, pp. 122-135, 2014.

[75] A. Abuirneileh, A. Talhouni, and I. W. A. Alsalahat, "Vanillin reduces intestinal smooth muscles contractility," African
Journal of Pharmacy and Pharmacology, vol. 9, pp. 33-37, 2015.

[76] R. S. Ramsewak, M. G. Nair, S. Murugesan, W. J. Mattson, and J. Zasada, "Insecticidal fatty acids and triglycerides fromDirca palustris," Journal of Agricultural and Food Chemistry, vol. 49, no. 12, pp. 5852-5856, 2001.

[77] J. Gokulakrishnan, E. Kuppusamy, D. Shanmugam, A. Appavu, and K. Kaliyamoorthi, "Pupicidal and repellent activities of Pogostemon cablin essential oil chemical compounds against medically important human vector mosquitoes," Asian Pacific Journal of Tropical Disease, vol. 3, no. 1, pp. 26-31, 2013.

[78] S. Senthil-Nathan, "A review of resistance mechanisms of synthetic insecticides and botanicals, phytochemicals, and essential oils as alternative larvicidal agents against mosquitoes," Frontiers in Physiology, vol. 10, 2020.

[79] L. M. F. Tresvenzol, J. R. Paula, P. H. Ferri, and F. N. M. oliveira, "Composition and chemical variability in the essential oil from leaves ofMemora nodosa(silva manso) miers," Journal of Essential Oil Research, vol. 22, no. 3, pp. 237-240, 2010.

[80] S. F. Soares, L. M. F. Borges, R. de Sousa Braga et al., "Repellent activity of plant-derived compounds against amblyomma cajennense (Acari: ixodidae) nymphs," Veterinary Parasitology, vol. 167, no. 1, pp. 67-73, 2010.

[81] G. Jillani and R. C. Saxena, "Repellent and feeding deterrent effects of turmeric oil, sweetly, neem oil, and neem leared insecticide against lesser grain borer (Coleoptera: Bostrichidae)," Journal of Economic Entomology, vol. 83, pp. 629-634, 1990.

[82] M. Fazolin, C. R. d. Costa, J. E. d. O. Damaceno, E. S. d. Albuquerque, A. S. d. S. Cavalcante, and J. L. V. Estrela, "Fumigação de milho para o controle do gorgulho utilizando caule de Tanaecium nocturnum (Bignoniaceae)," Pesquisa Agropecuária Brasileira, vol. 45, no. 1, pp. 1-6, 2010.

[83] M. O. Omolo, D. Okinyo, I. O. Ndiege, W. Lwande, and A. Hassanali, "Repellency of essential oils of some Kenyan plants against Anopheles gambiae," Phytochemistry, vol. 65, no. 20, pp. 2797-2802, 2004.

[84] H. F. Khater, "Prospects of botanical biopesticides in insect pest management," Pharmacologia, vol. 3, no. 12, pp. 641-656, 2012.

[85] H. Khater, "Bioactivity of essential oils as green biopesticides: recent global scenario," in Essentials Oils. II. Recent Progress in Medicinal Plants, vol. 37, pp. 151-218, Studium Press LLC, Washington, DC, USA, 2013.

[86] J. Islam, K. Zaman, K. Zaman, S. Duarah, P. S. Raju, and P. Chattopadhyay, "Mosquito repellents: an insight into the chronological perspectives and novel discoveries," Acta Tropica, vol. 167, pp. 216-230, 2017. 